\title{
Reclaiming Habit for Institutional Economics
}

\author{
by Geoffrey M. Hodgson
}

3 March 2003

Published in Journal of Economic Psychology 25(5), October 2004.

\author{
The Business School, University of Hertfordshire, Mangrove Road, Hertford, Hertfordshire SG13 8QF, UK \\ http://www.herts.ac.uk/business/esst/Staff/g-hodgson/hodgson.html \\ http://www.geoffrey-hodgson.ws \\ Address for correspondence: \\ Malting House, 1 Burton End, West Wickham, Cambridgeshire CB1 6SD, UK \\ g.m.hodgson@herts.ac.uk
}

KEY WORDS: habits, instincts, evolution, institutions, pragmatism

JEL classification: B15, B52, D80

\begin{abstract}
This paper reviews the concept of habit and its relation to institutions. The following questions are addressed: What are habits? Why have they evolved? How do institutions affect them? And what are some of the implications for economic analysis? It is argued that the early pragmatist and institutionalist though of William James, John Dewey and Thorstein Veblen remains a useful guide in this area, for further research today.
\end{abstract}




\title{
Reclaiming Habit for Institutional Economics
}

\author{
by Geoffrey M. Hodgson
}

To acknowledge the role of habit is to acknowledge much more than our settled ways, or repetitive human behaviour. ${ }^{1}$ Habit is not the same as ritual or repetition (Rook, 1999). We are all 'creatures of habit' but this is more than a mere idiosyncrasy, sluggishness or conservatism on our part. Instead, the reason why we have evolved the capacity to form habits is to deal with the uncertainty, complexity and variability of circumstances that we have endured over hundreds of thousands of years. Furthermore, habituation is a social mechanism, which typically involves the imitation of others, or results from behaviour that is repeatedly constrained by others. Habits, in short, are tied up with social institutions.

The aim of this short paper is to present this perspective on habit in summary form. No aspect of the argument is explored fully, but reference is made to relevant literature. It should also be added that the perspective outlined here is very similar to that proposed around a hundred years ago by the pragmatist philosophers and psychologists William James (18421910) and John Dewey (1859-1952), and the institutional economist Thorstein Veblen (18571929). Accordingly, the narrative involves some quotations from these and other writers of this early period. This is not for mere antiquarian interest, but to draw attention to a lost quarry of ideas of enormous endurance and relevance for today. Fuller cases for a rehabilitation of the Jamesian, Veblenian and institutionalist perspective are made elsewhere (Twomey, 1998; Hodgson, forthcoming). The crucial point is that the concept of habit is not only essential for economic psychology but also provides a crucial component in the understanding of interactions between institutions and individuals.

The following questions are addressed sequentially: What are habits? Why have they evolved? How do institutions affect habits and how do habits affect institutions? And what are some of the implications for economic analysis?

\section{What are habits?}

For James, Veblen and Dewey, habit was a propensity or disposition. It did not mean behaviour as such. James (1893, p. 143) proclaimed: 'Habit is thus the enormous fly-wheel of society, its most precious conservative agent.' Veblen (1898a, p. 390) wrote of 'a coherent structure of propensities and habits which seeks realisation and expression in an unfolding activity'. Veblen (1898b, p. 188) also remarked that 'man mentally digests the content of habits under whose guidance he acts, and appreciates the trend of these habits and propensities.' As John Dewey (1922, p. 42) put it: 'The essence of habit is an acquired predisposition to ways or modes of response.'

\footnotetext{
1 The author is very grateful to Paul Downward and Peter Earl for comments on an earlier draft of this paper.
} 
The mechanisms of habit are largely unconscious, but they may press on our awareness. Habits are submerged repertoires of potential behaviour; they can be triggered or reinforced by an appropriate stimulus or context. The meaning of habit adopted by Veblen, the pragmatist philosophers and instinct psychologists was of an acquired proclivity or capacity, which may or may not be actually expressed in current behaviour. Repeated behaviour is important in establishing a habit. But if we acquire a habit we do not necessarily use it all the time. It is a propensity to behave in a particular way in a particular class of situations. ${ }^{2}$

This conception of habit contrasts with that used by some other authors. For example, Gary Becker (1992, p. 328) wrote: 'I define habitual behavior as displaying a positive relation between past and current consumption'. Becker here defines habit not as a behavioural propensity but as sequentially correlated behaviour. In contrast, the view of habit here is of a disposition, which, once acquired, is not necessarily realised in any future behaviour. Habit is a causal mechanism, not merely a set of correlated events.

One of the sources of this behaviourist definition is a reluctance to remove reason and belief from the driving seat of human action. If habits affect behaviour then it is wrongly feared that reason and belief will be dethroned. The concern is that volition would be replaced by mechanism. However, reasons and beliefs themselves depend upon habits of thought. Habits act as filters of experience and the foundations of intuition and interpretation. In pragmatist thought, habit is the grounding of both reflective and non-reflective behaviour. This does not make belief, reason or will any less important or real. ${ }^{3}$

Central to most strands of modern realist philosophy is the distinction between the potential and the actual, where in each case the former are more fundamental than the latter. This distinction is traceable back to Aristotle. Science is about the discovery of causal laws or principles. Causes are not events; they are generative mechanisms that can under specific conditions give rise to specific events. For example, a force impinging on an object does not always make that object move. The outcome also depends on friction, countervailing forces, and other factors. Hence there must be a distinction between an observed empirical regularity and any causal law that lies behind it. This partly is why habit is defined as a disposition or propensity and is distinguished from behaviour. ${ }^{4}$

From the pragmatist and institutionalist perspective, habits are foundational to all thought and behaviour. All deliberations, including rational optimisation, themselves rely on habits and rules (Hodgson, 1997; Vanberg, 2002). In that habits are triggered by circumstances or stimuli, they have a conditional or rule-like structure. Even rational optimisation, if and when possible, must involve rules. In turn, as suggested above, rules have to become ingrained in habits in order to be deployed by agents. Hence rational deliberation always depends on prior habits and rules as props (Hodgson, 1988). The view of Becker (1992) and others that rational choices can lead to the formation of habits is valid. But what is also being proposed here is that rational choices themselves are always and necessarily reliant on prior habits.

\footnotetext{
2 The conception of a habit as a propensity is also found in more recent works such as Camic (1986), Margolis (1994), Murphy (1994), Kilpinen (2000) and others. The works of James (1893) and Dewey (1922) remain two of the classic and best accounts of the nature of habit as understood here.

3 The definition and treatment of habit here contrasts with neoclassical analyses of habit, where habit is seen as based upon, and derivable from, rational behaviour (Lluch, 1974; Phlips and Spinnewyn, 1984; Becker and Murphy, 1988; Becker, 1992).

${ }^{4}$ See for example Bhaskar (1975), Harré and Madden (1975), Popper (1990).
} 


\section{Why has the capacity to form sophisticated habits evolved in humans?}

Habit must be distinguished from instinct. Instincts are inherited behavioural dispositions that, when triggered, take the form of reflexes, urges or emotions. They can often be suppressed or diverted. Newborn babies inherit the means of recognition and imitation of some vocal sounds, as well as some elemental understanding of linguistic structure (Pinker, 1994). There are also instinctive reflexes to clutch and suckle, and much else. The removal of all instincts would result in the tragic absurdity of a newborn with no means to begin to interact with its world. It is likely that particular circumstances can trigger inherited instincts such as fear, imitation or sexual arousal. It is beyond the point to argue that acquired habit or socialisation are much more important than instinct. Many of our dispositions and much of our personality are formed after birth. But the importance of socialisation does not deny the necessary role of instinct. Both instinct and habit are essential for individual development. Instinctive behaviour and socialisation are not always rivals but often complements. ${ }^{5}$

Turning again to habits, a frequent justification of their existence is they help 'economize on the cost of searching for information' (Becker, 1992, p. 331). Robert Frank (1987, p. 23) similarly wrote: 'Cognitive capacity is a scarce resource like any other. ... Given scarce cognitive resources, to rely on habit and other nonrational decision rules is fully rational.' This may be true (as long as we can swallow the questionable proposition that a 'fully rational' choice is not necessarily a fully informed choice). But it cannot explain why the adopted decision rules or propensities are habitual rather than instinctive; it cannot explain why they are learned rather than simply biologically inherited.

Humans have faced the problems of costly information search for hundreds of thousands of years. So we may ask: what is to stop natural selection eventually creating sophisticatedly programmed instincts that are sufficiently flexible to deal with most circumstances, and reduce the 'cost of searching for information'? If evolved instincts are so powerful, why do they not eventually provide the complete apparatus of human cognition and action? Veblen addressed this question and argued that instincts on their own were too blunt or vague as instruments to deal with the more rapidly evolving exigencies of the human condition. Veblen (1914, p. 6) wrote:

Yet the dependence of the scheme of life on the complement of instinctive proclivities hereby become less immediate, since a more or less extended logic of ways and means comes to intervene between the instinctively given end and its realisation; and the lines of relation between any given instinctive proclivity and any particular feature of human conduct are by so much the more devious and round-about and the more difficult to trace. The higher the degree of intelligence and the larger the available body of knowledge current in any given community, the more extensive and elaborate will be the logic of ways and means interposed between these impulses and their realisation ...

This means that habits, being adaptable, are necessary to deal with the cognitive complexity of changing problems. Instincts remain vital but the modificatory power of instincts becomes relatively more important. For Veblen, habits were additional and necessary means for instinctive proclivities to be pursued in a changing environment. As Veblen (1914, pp. 6-7) explained:

\footnotetext{
5 Work in evolutionary psychology is relevant here. See for example Cosmides and Tooby (1994), Cummins and Allen (1998), Buss (1999).
} 
The instinctive proclivities are essentially simple and look directly to the attainment of some concrete objective end; but in detail the ends so sought are many and diverse, and the ways and means by which they may be sought are similarly diverse and various, involving endless recourse to expedients, adaptations, and concessive adjustment between several proclivities ...

Instincts were 'essentially simple' and directed to 'some concrete objective end'. Habits were the means by which the pursuit of these ends could be adapted in particular circumstances. In comparison to instinct, habit is a relatively flexible means of adapting to complexity, disturbance and unpredictable change. But they must do this without continuous, costly and excessive adaptation.

Veblen's line of argument suggests that humans faced diverse and changing problems in their evolution and this helped sophisticated mechanisms of habit formation to emerge. On more specific lines it could be argued that capacities for sophisticated habit formation and cultural growth emerged among humans to deal with a changing and unpredictable climatic and natural environment. Environmental change, particularly climatic change, is now emerging as a major explanation of the evolution of both intelligence and culture among humans (Potts, 1996; Calvin, 2002).

Generally, and in sum, the human capacity to form habits has evolved as a result of highly variable environmental and other conditions. The next (fairly obvious) question is why the same capacity to form sophisticated and adaptable habits is not found to the same degree among other species, who endured similar environmental variations. The answer is in terms of the relatively more sophisticated development of social structures among early humanoids. Individual humans had to deal with a relatively complex social as well as natural environment. They evolved the capacity to create and sustain relatively complex social structures, but at the same time they had to evolve the capacities of communication and interpretation so that each individual could cope with his or her social circumstances. Habituation and sociality are linked together. The manner of this linkage is outlined in the next section.

\section{The interplay of habits and institutions}

Institutions are systems of established and prevalent social rules that structure social interactions. Institutions also involve some shared conceptions. Language, money, law, systems of weights and measures, traffic conventions, table manners, firms (and other organisations) are all institutions. This definition, in its broad emphasis on systems of rules, is similar to that adopted by Douglass North (1990) and others.

However, we need to consider why institutions are durable, how they structure social interactions, and in what senses they are established and embedded. The durability of some institutions stems from the fact that they can usefully create stable expectations of the behaviour of others. This is particularly important when the institutional convention is a viable solution to a coordination game. In other cases, however, institutional durability must result from additional factors, as the coordination game setup is not universal and players sometimes have incentives to defect or cheat.

Generally, institutions enable ordered thought, expectation and action, by imposing form and consistency on human activities. They depend upon the thoughts and activities of individuals but are not reducible to them. Institutions both constrain and enable behaviour. 
Generally, the existence of rules implies constraints. However, the constraint can open up possibilities: it may enable choices and actions that otherwise would not exist. For example, the rules of language allow us to communicate; traffic rules help traffic to flow more easily and safely. Regulation is not the antithesis of freedom; it can be its ally.

But the hidden and most pervasive feature of institutions is their capacity to mould and change aspirations, instead of merely enabling them. This aspect of institutions is hitherto relatively neglected in the 'new institutional economics'. Because institutions not only depend upon the activities of individuals but also constrain and mould them, this positive feedback gives institutions even stronger self-reinforcing and self-perpetuating characteristics.

How do institutions mould our preferences or purposes? Crucially, our habits help to make up our preferences and dispositions. When new habits are acquired or existing habits change, then our preferences alter. Dewey (1922, p. 40) thus wrote of 'the cumulative effect of insensible modifications worked by a particular habit in the body of preferences'.

Institutional changes and constraints can cause changes in habits of thought and behaviour. Institutions constrain our behaviour and develop our habits in specific ways. What does happen is that the framing, shifting and constraining capacities of social institutions give rise to new perceptions and dispositions within individuals. Upon new habits of thought and behaviour, new preferences and intentions emerge. Alfred Marshall (1949, p. 76) observed 'the development of new activities giving rise to new wants'. But we need to know how this happens. Veblen (1899, p. 190, emphasis added) was more specific about the psychological mechanisms involved: 'The situation of today shapes the institutions of tomorrow through a selective, coercive process, by acting upon men's habitual view of things'.

We are typically constrained in our actions. Accordingly, we acquire habits consistent with the operation of these constraints. Even when these constraints are removed, habits dispose us to act or think in the same old way. This provides a reconstitutive mechanism of 'downward causation' (Hodgson, 2002, 2003; Sperry, 1991) from institutions to individuals. The crucial point in the argument here is to recognise the significance of reconstitutive downward causation on habits, rather than merely on behaviour, intentions or beliefs. Clearly, the definitional distinction between habit (as a propensity or disposition) and behaviour (or action) is essential to make sense of this statement. Once habits become established they become a potential basis for new intentions or beliefs.

But a second point is also of vital significance. It is a central tenet of the pragmatist philosophical and psychological perspective to regard habit and instinct as foundational to the human personality. Reason, deliberation and calculation emerge only after specific habits have been laid down; their operation depends upon such habits. In turn, the development of habits depends upon prior instincts. Instincts, as typically defined, are inherited. Accordingly, reconstitutive downward causation upon instincts is not possible.

The ongoing acquisition and modification of habits is central to individual human existence. For example, much deliberative thought is dependent on, as well as being coloured by, acquired habits of language. In addition, to make sense of the world we have to acquire habits of classification and habitually associated meanings. The crucial point is that all action and deliberation depend on prior habits that we acquire during our individual development. Hence habits have temporal and ontological primacy over intention and reason. As we have seen, reconstitutive downward causation works by creating and moulding habits. Habit is the crucial and hidden link in the causal chain. 
Accordingly, as long as we can explain how institutional structures give rise to new or changed habits, then we have an acceptable mechanism of reconstitutive downward causation. In contrast, we cannot identify any causal mechanism where institutions lead directly to the reconstitution of purposes or beliefs. Institutions may lead directly to changes in some intentions, but only by acting as non-reconstitutive influences or constraints. To provide a reconstitutive causal mechanism, we have to point to factors that are foundational to purposes, preferences and deliberation as a whole. This is where habits come in.

As a result, institutions are social structures with the capacity for reconstitutive downward causation, acting upon ingrained habits of thought and action. Powers and constraints associated with institutional structures can encourage changes in thought and behaviour. In turn, upon these repeated acts, new habits of thought and behaviour emerge. It is not simply the individual behaviour that has been changed: there are also changes in habitual dispositions. In turn, these are associated with changed individual understandings, purposes and preferences.

If we take the above arguments seriously, then we must recognise that our aspirations and choices are cast in institutional moulds (Clark, 1997; Lane et al. 1996). Much of our deliberation takes place within and through social institutions. We use institutions and their routines as templates in the construction of our habits, intentions and choices.

Consequently, reconstitutive downward causation is an indelible feature of social life. Yet it is absent from mainstream economics. Some economists, including Becker (1996, p. 225), describe situations where individual purposes and choices are moulded as 'brainwashing'. This involves a neglect of the undesigned institutional processes of persuasion. The mechanisms of reconstitutive downward causation are far more widespread and subtle than the overt 'brainwashing' of individuals. Typical of many economists, Becker recognises nothing in between 'brainwashing' on the one hand, and 'free choice' based on given preference functions, on the other. The truth is that most of social behaviour lies between these two extremes.

\section{Conclusion}

If we believe that humans are rational, then we must provide an account of how rationality has evolved in the human species (Hodgson, 1998). Similarly, the capacity of humans to deliberate and calculate must have evolved out of other, less deliberative, mental capacities. Instincts evolved before habits. Among animals with relatively well-developed nervous systems, blunt instinctive impulses can prompt more particular behaviours that cause ingrained habitual adaptations. Among animals with the most well-developed nervous systems, habits are the means by which the rules and categorisations of rational deliberation are enacted. In the development of both the individual and the species, instinct is necessarily prior to habit, and habit is necessarily prior to rational deliberation.

Standard formulations of the rationality axioms are consistent with the existence of habitual behaviour (Becker and Murphy, 1988). Indeed, it is now argued that these axioms also apply to 'honeybees, ants and schooling fish' (Landa, 1999, p. 95), or even bacteria (Tullock, 1994). The problem with these axioms is not that they are too narrow but they are too broad. The rationality assumptions neither tell us what is particularly human, nor describe human capabilities or limitations in particular details or contexts (Hodgson, 2001), nor show how a rational problem-solver tackles ongoing challenges (Vanberg, 2002). 
An emphasis on the capacity to form multiple, highly sophisticated habits would be an emphasis on an attribute that is specifically human. In addition, putting habit first in economic analysis would be to see deliberative rationality as necessarily based on habits, rather than the other way round. Nobel Laureates Gary Becker (1962) and Kenneth Arrow (1986) have long ago hinted that an alternative conception of human agency, based on habit, may be at least as powerful as the principles of rationality. The problem is that this habit-based conception has not, as yet, been further developed. This is an important area of enquiry for future theoretical and empirical research.

An important implication of the idea of interaction between individuals and habits through mechanisms of habituation is that it confounds explanations of social phenomena that are exclusively unidirectional. It provides a means of avoiding both, on the one hand, the exclusively 'top down' explanations of individuals in terms of cultures, structures or institutions, and on the other hand, the exclusively 'bottom up' modes of explanation that attempt to start from individuals alone. The conceptual problems with these two alternatives have been visited elsewhere (Hodgson, 1988, 1998, forthcoming). The approach sketched here avoids these two extremes, and instead is both interactionist and evolutionary, paying heed to both the uncertainty of the human condition and its situation in evolutionary and historical time. 


\section{References}

Arrow, Kenneth J. (1986). Rationality of Self and Others in an Economic System. Journal of Business, 59(4.2), October, S385-S399.

Becker, Gary S. (1962). Irrational Behavior and Economic Theory. Journal of Political Economy, 70(1), February, 1-13.

Becker, Gary S. (1992). Habits, Addictions and Traditions. Kyklos, 45, Fasc. 3, 327-346.

Becker, Gary S. (1996). Accounting for Tastes. Cambridge, MA: Harvard University Press.

Becker, Gary S. and Murphy, Kevin M. (1988). A Theory of Rational Addiction. Journal of Political Economy, 96(4), 675-700.

Bhaskar, Roy (1975). A Realist Theory of Science, $1^{\text {st }}$ edn.. Leeds: Leeds Books.

Buss, David M. (1999). Evolutionary Psychology: The New Science of the Mind. Needham Heights, MA: Allyn and Bacon.

Calvin, William H. (2002). A Brain for All Seasons: Human Evolution and Abrupt Climate Change. Chicago: University of Chicago Press.

Camic, Charles (1986). The Matter of Habit. American Journal of Sociology, 91(5), March, 1039-1087.

Clark, Andy (1997). Economic Reason: The Interplay of Individual Learning and External Structure. In Drobak, John N. and Nye, John V. C. (eds) (1997). The Frontiers of the New Institutional Economics. San Diego and London: Academic Press, 269-290.

Cosmides, Leda and Tooby, John (1994). Better than Rational: Evolutionary Psychology and the Invisible Hand. American Economic Review (Papers and Proceedings), 84(2), May, 327-332.

Cummins, Denise Delarosa and Allen, Colin (eds) (1998). The Evolution of Mind. Oxford and New York: Oxford University Press.

Dewey, John (1922). Human Nature and Conduct: An Introduction to Social Psychology, 1st edn.. New York: Holt.

Frank, Robert H. (1987). Shrewdly Irrational. Sociological Forum, 2(1), Winter, 21-41.

Harré, Rom and Madden, Edward H. (1975). Causal Powers: A Theory of Natural Necessity. Oxford: Basil Blackwell.

Hodgson, Geoffrey M. (1988). Economics and Institutions: A Manifesto for a Modern Institutional Economics. Cambridge and Philadelphia: Polity Press and University of Pennsylvania Press.

Hodgson, Geoffrey M. (1997). The Ubiquity of Habits and Rules. Cambridge Journal of Economics, 21(6), November, 663-684.

Hodgson, Geoffrey M. (1998). The Approach of Institutional Economics. Journal of Economic Literature, 36(1), March, 166-192.

Hodgson, Geoffrey M. (2001). How Economics Forgot History: The Problem of Historical Specificity in Social Science. London and New York: Routledge. 
Hodgson, Geoffrey M. (2002). Reconstitutive Downward Causation: Social Structure and the Development of Individual Agency' in Fullbrook, Edward (ed.) (2002). Intersubjectivity in Economics: Agents and Structures. London and New York: Routledge, 159-180.

Hodgson, Geoffrey M. (2003). The Hidden Persuaders: Institutions and Individuals in Economic Theory. Cambridge Journal of Economics, 27(2), March, 159-175.

Hodgson, Geoffrey M. (forthcoming). The Evolution of Institutional Economics: Agency and Structure in American Institutionalism. London and New York: Routledge.

James, William (1893). Psychology: Briefer Course. New York: Holt.

Kilpinen, Erkki (2000). The Enormous Fly-Wheel of Society: Pragmatism's Habitual Conception of Action and Social Theory. Helsinki: University of Helsinki.

Landa, Janet (1999). Bioeconomics of Some Nonhuman and Human Societies: New Institutional Economics Approach. Journal of Bioeconomics, 1(1), 95-113.

Lane, David, Malerba, Franco, Maxfield, Robert and Orsenigo, Luigi (1996). Choice and Action. Journal of Evolutionary Economics, 6(1), 43-76.

Lluch, C. (1974). Expenditures, Savings and Habit Formation. International Economic Review, 15, 786-797.

Margolis, Howard (1994). Paradigms and Barriers: How Habits of Mind Govern Scientific Beliefs. Chicago: University of Chicago Press.

Marshall, Alfred (1949). The Principles of Economics, 8th (reset) edn. (1st edn. 1890). London: Macmillan.

Murphy, James Bernard (1994). The Kinds of Order in Society. In Mirowski, Philip (ed.) (1994). Natural Images in Economic Thought: Markets Read in Tooth and Claw. Cambridge and New York: Cambridge University Press, 536-582.

North, Douglass C. (1990). Institutions, Institutional Change and Economic Performance. Cambridge: Cambridge University Press.

Phlips, Louis and Spinnewyn, F. (1984). True Indexes and Rational Habit Formation. European Economic Review, 24, 209-223.

Pinker, Steven (1994). The Language Instinct: The New Science of Language and Mind. London and New York: Allen Lane and Morrow.

Popper, Karl R. (1990). A World of Propensities. Bristol: Thoemmes.

Potts, Richard (1996). Humanity's Descent:The Consequences of Ecological Instability. New York: William Morrow.

Rook, Dennis W. (1999). Ritual' in Earl, Peter E. and Kemp, Simon (eds) (1999). The Elgar Companion to Consumer Research and Economic Psychology. Cheltenham: Edward Elgar), 506-509.

Sperry, Roger W. (1991). In Defense of Mentalism and Emergent Interaction. Journal of Mind and Behavior, 12(2), 221-246.

Tullock, Gordon (1994). The Economics of Non-Human Societies. Tuscon, Arizona: Pallas Press.

Twomey, Paul (1998). Reviving Veblenian Economic Psychology. Cambridge Journal of Economics, 22(4), July, 433-448. 
Vanberg, Viktor J. (2002). Rational Choice versus Program-Based Behavior: Alternative Theoretical Approaches and Their Relevance for the Study of Institutions. Rationality and Society, 14(1), Summer, 7-53.

Veblen, Thorstein B. (1898a). Why Is Economics Not an Evolutionary Science? Quarterly Journal of Economics, 12(3), July, 373-397. Reprinted in Veblen, Thorstein B. (1919). The Place of Science in Modern Civilization and Other Essays. New York: Huebsch.

Veblen, Thorstein B. (1898b). The Instinct of Workmanship and the Irksomeness of Labor. American Journal of Sociology, 4(2), September, 187-201. Reprinted in Veblen, Thorstein B. (1934). Essays on Our Changing Order, ed. Leon Ardzrooni. New York: The Viking Press.

Veblen, Thorstein B. (1899). The Theory of the Leisure Class: An Economic Study in the Evolution of Institutions. New York: Macmillan.

Veblen, Thorstein B. (1914). The Instinct of Workmanship, and the State of the Industrial Arts. New York: Macmillan. 